\title{
EFFECT OF GIBBERELLIC ACID ON THE PERSISTENCE OF CERTAIN PESTICIDES ON/IN GRAPE FRUITS
}

\author{
[28] \\ Nevein S. Ahmed'; Z.H. Zidan²; W. El-Sayed ${ }^{2}$ and Rania, M. Abdel-Hamid' \\ 1- Central Agric. Pesticides Laboratory. Agric. Research Center, Dokki, Giza, Egypt \\ 2- Plant Protection Department, Faculty of Agriculture, Ain Shams University, Shoubra \\ El-Kheima, Cairo, Egypt
}

Keywords: Diniconazole, Fenitrothion, Plant growth regulator, Gibberellic acid, Residues

\section{ABSTRACT}

Recommended application was done by spray regime for two pesticides, namely diniconazole, fenitrothion and a plant growth regulator (gibberellic acid) and their mixtures. Their residues were determined after different successive treatments in and on grape fruits in two consecutive years. The initial deposits of the fungicide diniconazole when used alone were 0.49 and 0.50 ppm for 2006 and 2007 , respectively. While the initial deposits of fenitrothion reached to 11.35 and $11.19 \mathrm{ppm}$ for the same interval, respectively. Initial deposits of the plant growth regulator gibberellic acid were 30.52 and 30.42 ppm for the same period, respectively.

After mixing the tested pesticides and the plant growth regulator, the initial deposits loss reached 38.77 and $42.0 \%$ for diniconazole, 43.08 and $48.16 \%$ for fenitrothion and 6.88 and $7.00 \%$ for gibberellic acid for the same seasons, respectively. A significant degradation was recorded with the mixture of the two tested pesticides and plant growth regulator compared with that occurred when pesticide was used alone at the two studied seasons.

\section{INTRODUCTION}

Grapes (Vitis vinifera L.) belong to the world's largest fruit crops with a global production, they contain large amounts of phytochemicals which offer health benefits (Mandal et al 2010). Grape crop is mainly subjected to infestation with mealy bugs, powdery mildew and berry rot. The insecticide fenitrothion (Sumithion) is recommended for controlling mealy bugs and thrips, while the triazole fungicide diniconazole (Sumi-eight) is recommended for controlling powdery mildew and berry rot according to pest control program, (Ministry of Agriculture and Land Reclamation, Egypt, 2001). Four applications of gibberellic acid (GA3) are currently used to increase the berry size of Thompson Seedless grapes. GA3 significantly improved berry size and cell elongation, it could cause corckiness of stems and delayed ripening, (Singh et al 1978 and Mervet et al 2001).

The wide use of pesticides in agriculture and their background levels in the environment could be a source of many biochemical and physiological disturbances in plants, animals and human (Mahmoud 2004). Plant growth regulators as gibberellic acid (GA3) are important in regulating the plant growth in which the formation of bunch of flower, berry set, berry enlargement, extension of bunch of grapes, dilution of berry in a bunch of grapes, preventing berry cracking, killing pollens and causing grape varieties having seeds becoming seedless, and has no harmful effect on human health. However, the application time, dose, the age, the growth period, etc. of the plant that the application is done on, are important (Korkutal et al 2008).

The present study aimed to investigate the persistence of diniconazole, fenitrothion, gibberellic acid and their mixtures in and on grape fruits and the preharvest interval $(\mathrm{PHI})$ for each of the tested pesticides alone and in mixtures. 


\section{MATERIALS AND METHODS}

This work was carried out during 2006 and 2007 seasons on twenty years old vigorous fruitful Thompson seedless grapevines grown in private vineyard at Kalubia governorate. A triazole systemic fungicide namely diniconazole in the form of sumieight $5 \% \mathrm{EC}$, fenitrothion, non systemic insecticide in the form of sumithion $50 \%$ EC and a plant growth regulator as gibberellic acid in form of Berlex $10 \%$ tablet were applied according to the following mode of application.

\section{1) Experimental Design}

The cultivated areas with grapevines were divided into 5 plots, each plot contained 10 vines. The following treatments were carried out as follows:

Treatment (1): Ten vines were left without treatment as a control and for recovery test.

Treatment (2): Ten vines were treated with diniconazole at $35 \mathrm{ml} / 100 \mathrm{~L}$ water.

Treatment (3): Ten vines were treated with fenitrothion at $150 \mathrm{ml} / 100 \mathrm{~L}$ water.

Treatment (4): Ten vines were treated with gibberellic acid at 10-20-30-40 ppm, respectively as shown in Table (1).

Treatment (5): Ten vines were treated with mixtures of diniconazole, fenitrothion and gibberellic acid at the above mentioned rates.

Spray regime was done as follows: (1) three treatments for each pesticide alone, (2) Four treatments for the plant growth regulator. (3) Only one treatment for the mixture of each pesticide with the plant growth regulator, (4) Two treatments for the mixture of the two pesticides and the plant growth regulator. The initial sample was taken after the fourth spray for each pesticide alone, the plant growth regulator and the mixture of the two pesticides with the plant growth regulator (Table 1).

\section{2) Sampling}

Representative samples from grapes were taken at random after one hour, 1, 2, 5, 7, 11, 14, 19 and 23 days from treatments, for pesticides and plant growth regulator residue analysis. Subsampling was done, where three samples of $50 \mathrm{~g}$ of treated grapes were taken. Sub samples were kept in clean poly-ethylene bags and stored at $20^{\circ} \mathrm{C}$ in a deep freezer until the time of residue analysis.

\section{3) Extraction and Clean up}

Methanol was adopted for the extraction of diniconazole in a technique mentioned by Mallhof (1975) instead of acetone, and cleaned up using the coagulating solution used by Johnson (1963). Residues of fenitrothion were analyzed according to the technique developed by M.W.H.C.A., Netherlands (1988). The extracts of fenitrothion were cleaned up by Malhat (2006) method. The extraction technique described by Gordon and Pankratz (1968) was followed for the extraction of gibberellic acid.

\section{4) Residues Determination}

\subsection{Diniconazole}

Hewlett Packard 6890 series gas chromatography system equipped with electron capture detector (ECD) was used for the determination of diniconazole residues at the following operating condition using DB-17 Column (15 $\mathrm{m} \times 0.32 \mathrm{~mm} \times$ $0.52 \mu \mathrm{m}$ film thickness). The operating temperatures were 220,320 and $320^{\circ} \mathrm{C}$ for the column, injector and detector, respectively, using $\mathrm{N}_{2}$ gas as carrier gas with a flow rate of $4 \mathrm{ml} / \mathrm{min}$.

\subsection{Fenitrothion}

Quantitative analysis of fenitrothion residues were performed by a Hewlett Packard 6890 series gas chromatography system equipped with Flame photometric detector (FPD), operated in the phosphorus mode (525 nm filter under the following operation conditions: The used column was: Capillary column was P.As-1701(14\%cyanoprophyl phenyl methyl polysiloxane) $(30 \mathrm{~m} \times 0.32 \mathrm{~mm} \times 0.25$ $\mu \mathrm{m}$ film thickness). The operating temperatures were 230,240 and $250^{\circ} \mathrm{C}$ for the column, injector and detector, respectively, using $\mathrm{N}_{2}$ gas as carrier gas with a flow rate of $4 \mathrm{ml} / \mathrm{min}$. The hydrogen and air flow were 75 and $100 \mathrm{ml} / \mathrm{min}$

\subsection{Gibberellic acid}

Determination of gibberellic acid residues was done by HPLC Agilent 1100 equipped with diode array detector under the following operation conditions: Column: Zorbax SBC18 $(30 \mathrm{~m} \times 0.32 \mathrm{~mm} \times$ $0.25 \mu \mathrm{m}$ film thickness). The Mobile phase was: methanol/acetonitrile/water. (60/35/5.V/V/V) with a flow rate of $0.8 \mathrm{ml} / \mathrm{min}$. 
Table 1. Purpose of treatment, time of application and plant stages

\begin{tabular}{|c|c|c|c|c|c|c|c|}
\hline \multirow{2}{*}{$\begin{array}{l}\text { Purpose of } \\
\text { treatment }\end{array}$} & \multirow{2}{*}{$\begin{array}{c}\text { Time of } \\
\text { application }\end{array}$} & \multicolumn{6}{|c|}{ Treatments } \\
\hline & & D & $F$ & $\mathbf{G}$ & $D+G$ & $F+G$ & $D+F+G$ \\
\hline Elongation & $\begin{array}{l}10-13 \mathrm{~cm}^{3} \text { of } \\
\text { cluster length }\end{array}$ & & $\begin{array}{c}150 \mathrm{~cm}^{3} / 100 \mathrm{~L} \\
\text { water }\end{array}$ & 10 ppm & - & $\sqrt{ }$ & - \\
\hline First Thinning & $10 \%$ flowering & $\begin{array}{c}35 \mathrm{~cm}^{3} / 100 \mathrm{~L} \\
\text { water }\end{array}$ & - & $\begin{array}{l}10-20 \\
\mathrm{ppm}\end{array}$ & $\sqrt{ }$ & - & \\
\hline $\begin{array}{l}\text { Second Thin- } \\
\text { ning }\end{array}$ & $70 \%$ flowering & $\begin{array}{c}35 \mathrm{~cm}^{3} / 100 \mathrm{~L} \\
\text { water }\end{array}$ & $\begin{array}{c}150 \mathrm{~cm}^{3} / 100 \mathrm{~L} \\
\text { water }\end{array}$ & $\begin{array}{l}20-30 \\
\mathrm{ppm}\end{array}$ & 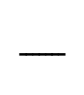 & & $\sqrt{ }$ \\
\hline Sizing & $\begin{array}{c}10-12 \mathrm{~mm} \text { of } \\
\text { berry size }\end{array}$ & $\begin{array}{c}35 \mathrm{~cm}^{3} / 100 \mathrm{~L} \\
\text { water }\end{array}$ & $\begin{array}{c}150 \mathrm{~cm}^{3} / 100 \mathrm{~L} \\
\text { water }\end{array}$ & 40 ppm & - & - & $\sqrt{ }$ \\
\hline
\end{tabular}

$\checkmark$ - treated with mixtures of diniconazole, fenitrothion and gibberellic acid at the recommended rates

\section{5) Recovery Studies}

Untreated samples of grape were spiked with known amounts of diniconazole, fenitrothion and gibberellic acid prior to extraction and clean up for recovery determination. These samples were passed through the entire process of extraction, then clean up and analysis as previously described. By following such techniques the rates of recovery for diniconazole, fenitrothion and gibberellic acid residues from spiked plant samples treated with $0.1,0.5$ and $1 \mathrm{ppm}$ were determined. The obtained results were corrected according to the recovery rate. Data in Table (2) proved the satisfactory rate of recovery, reaching 92.08, 101.29 and 91.79 in average for diniconazole, fenitrothion and gibberellic acid, respectively.

Table 2. Recovery percent of tested agrochemicals from spiked plant samples

\begin{tabular}{|c|c|c|c|}
\hline \multirow{2}{*}{$\begin{array}{c}\text { Fortified } \\
\text { limit } \\
\text { (ppm) }\end{array}$} & \multicolumn{3}{|c|}{ \% Average of recovery } \\
\cline { 2 - 4 } & Diniconazole & Fenitrothion & $\begin{array}{c}\text { Gibberellic } \\
\text { acid }\end{array}$ \\
\hline $\mathbf{0 . 1}$ & 90.97 & 99.88 & 89.32 \\
$\mathbf{0 . 5}$ & 91.23 & 100 & 92.75 \\
$\mathbf{1 . 0}$ & 94.06 & 104 & 93.32 \\
\hline Average & 92.08 & 101.29 & 91.79 \\
\hline \multicolumn{4}{|c|}{ RESULTS AND DISCUSSION } \\
\hline
\end{tabular}

\section{1) Persistence of diniconazole and its mixtures on $\&$ in grape fruits}

The dissipation of any compound depends on various factors, including plant species, chemical formulation, climatic conditions, physical phenomenon mainly volatilization, application method and chemical conditions in which sunlight play prominent role Mandal et al (2010).

Results in Table ( 3 and 4 ) indicated that the three pesticides when used alone showed higher residue levels than those recorded with their mixtures at most intervals during the two seasons. The initial deposits found after one hour from the fourth spray at 2006 were $0.49 \mathrm{ppm}$ (diniconazole alone) and $0.30 \mathrm{ppm}$ for its mixture with the two other pesticides with percent of loss difference 38.77. On the other hand, the initial deposits at 2007 were $0.50 \mathrm{ppm}$ for diniconazole alone and $0.29 \mathrm{ppm}$ for its mixture, with loss difference of $42.0 \%$ at the same interval.

The estimated half-life $\left(t_{1 / 2}\right)$ values for diniconazole alone were $22.49 \mathrm{hrs}$ and $25.32 \mathrm{hrs}$ for its mixture on\&in grape fruits at 2006, which reached 23.03 and $24.78 \mathrm{hrs}$, respectively at 2007 .

According to Codex Alimentarius Commission (2010), the maximum residue limits for diniconazole on/in grape fruits was $0.05 \mathrm{ppm}$. 
The corresponding recommended pre-harvest intervals $(\mathrm{PHI})$ were 7.0 and 5.0 days in the two seasons after application of diniconazole alone (D) and of its mixture (M-D), respectively. These results are in agreement with those of Hegazy et al (1999) who studied the residues of diniconazole on/in grape leaves and found that the safety period that should be waited before marketing grape leaves is at least three weeks to reach its MRL level (0.2 ppm).

\section{2) Persistence of fenitrothion and its mixtures on/in grape fruits}

Data presented in Tables (3 and 4) indicated that fenitrothion when used alone showed higher persistence compared to its mixtures at all intervals during the two studied seasons. The initial deposits one hour after the fourth spray in 2006 were 11.35 ppm for fenitrothion alone and $6.46 \mathrm{ppm}$ for its mixture, showing a loss of $43.08 \%$. On the other hand, the initial deposits in 2007 reached 11.19 ppm (fenitrothion) and $5.80 \mathrm{ppm}$ (its mixtures) with a loss of $48.16 \%$.

The $t_{1 / 2}$ 's for fenitrothion alone were $28.23 \mathrm{hrs}$ and 20.15 hrs for its mixture on/in grape fruits in 2006, compared with 26.72 and 19.21 hrs in 2007, respectively.

The level of pesticides residue is affected by many factors, i.e. applied rate, meteorological factors, biological aspects in addition to the nature and properties of the plant surface. The obtained results are in coincide with those reported by $\mathrm{He}$ gazy et al (1988-a) and Hegazy et al (1997a \& b).

According to Codex Alimentarius Commission (2010), the MRL's for fenitrothion on/in grape fruits was $(0.1 \mathrm{ppm})$. The obtained pre-harvest intervals (PHI's) were 9.0 and 7.0 days at the two seasons after application for fenitrothion alone (F) and its mixture of fenitrothion (M-F), respectively. The rapid disappearance of fenitrothion may be due to its high vapor pressure $\left(18 \mathrm{mPa}\right.$ at $\left.20^{\circ} \mathrm{C}\right)$. Similar findings were recorded by Hegazy et al (1997-b) and Hegazy et al (1999).

Generally, it was found that organophosphorus pesticides were degraded within short periods in plants and other environmental constituents (Al-Samariee et al 1988). The safe period for harvesting the organophosphorus insecticides treated vegetables ranged between 1 and 12 days post-treatment, depending on the chemistry of tested pesticide and kind of crop El-Sayed et al (1977).

\section{3) Persistence of gibberellic acid (GA3) and its mixtures on/in grape fruits}

The results given in Tables ( 3 and 4 ) indicated that gibberellic acid alone showed more persistence than its mixtures within all intervals during the two seasons.

The estimated half-life $\left(\mathrm{t}_{1 / 2}\right)$ values for gibberellic acid alone was $17.15 \mathrm{hrs}$ compared to $13.69 \mathrm{hrs}$ for its mixture on/in grape fruits at 2006, which reached 17.11 and 13.68 , respectively at 2007 .

Such data revealed that GA3 showed the greatest and fast degradation compared with the other two pesticides. According to (M.H.W.S.) Netherlands (2006), the maximum residue limits for GA3 on/in grape fruits was 5.0 ppm. The obtained (PHI's) were 4.0 and 2.0 days at the two seasons after application of GA3 alone $(G)$ and its mixture (M-G), respectively.

In this regard, Hegazy et al (1988-b) reported that paclobutrazol in grape leaves showed fast degradation during the first day after application, followed by slow decomposition through the experimental period until disappearance on\&in grape leaves. This short persistence in/on grape fruits could be attributed to a variety of environmental factors such as sunlight and temperature Lichtenstein (1972).

Besides, plant growth is also responsible to certain extent for decreasing the pesticide residue concentrations due to growth dilution effect (Walgenbach et al 1991). However, the degradation rates gradually decreased through the elongation of post-treatment interval.

The above results are in agreement with those obtained by Abdel-Hamid (2008) as they studied some environmental factors on the decomposition of diniconazole, fenitrothion and gibberellic acid after different intervals from exposure. The half life value in case of single pesticide revealed less value than that in case of mixing with the other compounds which emphasizes rapid decomposition rate of the tested compounds when mixed together.

From Tables (3) and (4), we found that the initial deposit of the tested pesticides alone was much higher than that of the pesticides mixtures, which may be attributed to the physical properties of the pesticides. Abdel-Hamid (2008) found that fenitrothion, diniconazole and gibberellic acid had lower $\mathrm{pH}$, conductivity, salinity, surface tension and viscosity with respect to the same pesticide in the mixture. She proved a strong relationship between pesticide residues and physical properties of spray solution. 
Nevein Ahmed; Zidan; El-Sayed and Rania Abdel-Hamid

Arab Univ. J. Agric. Sci., 18(2), 2010 
Tawfik and El-Sisi (1987) and El-Sisi et al (1995) reported that decreasing the $\mathrm{pH}$ values and increasing the viscosity of the insecticide spray solution caused increase in the initial deposits and decrease in the degradation rate.

Consequently, the mixture of GA3 and the two studied pesticides could be recommended to decrease the initial deposits of GA3 and two the pesticides in the mixture as well as their residues on/in grape fruits.

\section{REFERENCES}

Abdel-Hamid, Rania M. (2008). Chemical and Physical Interactions Between Plant Growth Regulators and Some Pesticides in Vineyards, pp: 51, 69. M.Sc. Thesis, Fac. of Agric., Ain Shams Univ., Cairo, Egypt.

Al-Samariee, A.I.; K.A.M. Shaker and M. AlBassomy (1988). Residue level of three organophosphorus insecticides in sweet pepped grown in commercial green houses. Pesticide Sci., (22): 189-194.

Codex Alimentarius Commission for Pesticides residues (CAC/PR) (2010). List of maximum residue limits for pesticides in food and animal feeds. Part-1. Joint FAO/WHO Food Standards Programme, Fao, Rome, Italy.

El-Sayed, M.M.; S.M.A. Dogheim; S.A. Hindi; A. Shahin and M. Abd El-Salam (1977). Persistence of certain organophosphorus insecticides on some vegetables. Bull. Ent. Soc. Egypt, Econ. Ser. (10): 41-45.

EL-Sisi, A.G.; A.F. Shehata; S.M. Radwan and Y.A. Kokab (1995). Effect of certain additives on physical and biological efficacy of some pesticides. $1^{\text {st }}$ Int. Conf. of Pest Control, Mansoura, Egypt. 4: 76-82.

Hegazy, M.E.A.; M.A. Kandil; M.A. Abd El-Baki; and M.M. Diab (1988-a). Residual fate of three organophosphorus pesticides on onion. Annals Agric. Sci., Fac., Agric., Ain Shams Unvi., Cairo, Egypt. 33(1): 1299-1307.

Hegazy, M.E.A.; M.M. Abu-Zahw; S.M. Doghiem and M.M. Diab (1988-b). Residues of growth regulator cutler in fruits and leaves of vine crop. Annals of Agric., Moshtohor, Zagazig Univ. Egypt. 30 (2): 241-250.

Hegazy, M.E.A.; M.M. Abu-Zahw; A.H. Bayoumy; S.A. Soliman and M.N.S. Haggag (1997-a). Behaviour of fenitrothion residues in potato tubers as affected by some processing steps. J. Agric. Res. Egypt.75 (1): 345-352.
Hegazy, M.E.A.; M.M. Abu-Zahw; A.H. Bayoumy; S.A. Soliman and M.N.S. Haggag (1997-b). Triazophos insecticide on/in moloukhia leaves and okra fruits. J. Agric. Res. Egypt, 75(2): 41-49.

Hegazy, M.E.A.; M.A. Abd El-Razik.; M.F. ElHadidi; M.M. Abu-Zahw; SH.A. Shokr and Y.S. Ibrahim (1999). Residual behavior of certain pesticides on and in grape leaves. Egyptian Journal of Agricultural Research. 77(1): 159-168.

Gordon, J. and H. Pankratz (1968). Fluorometric determination of gibberellic acid. J. Agric. Food Chem.,16: 520-522.

Johnson, D.P. (1963). Determination of seven insecticides residues in fruits and vegetables. J. A.O.A.C. 46: 234-237.

Korkutal, I.; E. Bahar and O. Gokhan (2008). The Characteristics of Substances Regulating Growth and Development of Plants and the Utilization of Gibberellic Acid (Ga ) in Viticulture. World Journal of Agricultural Sciences, 4(3): 321-325.

Lichtenstein, E.P. (1972). Environmental Factors Affecting Fate of Pesticides. pp. 190205. Nat. Acad. Sci., Nat. Res. Council. Report, USA.

Mahmoud, H.A. (2004). Biochemical Studies on the Behavior of Some Pesticides in Broad Bean Crop. p. 2. Ph.D. Thesis, Fac. of Agric., Cairo Univ., Egypt.

Malhat, F.M.M. (2006). Chemical Studies on the Distribution of Two Pesticide Residues (Etoxazole \& Fenitrothion) in and on Plant, Soil and Ecosystem. pp. 21-22. M.Sc. Thesis, Fac. of Science, Minoufiya Univ., Shebin El-Kom, Egypt.

Mallhof, E. (1975). Method for gas chromatographic determination of residue tokuthion and its Oxon in plants and soil samples. Pflanzenschutz-Nachrichten Bayer, 28(3): 382387.

Mandal, S.; S. Das and A. Bhattacharyya (2010). Dissipation study of thiophanate methyl residue in/on grapes (Vitis Vinifera (L.) in India. Bull. Environ. Contam. Toxicol. 84: 592595.

Mervet, A.K.; A. Alia; H. Ibrahim and Isis A. Rizk. (2001). Effect of sitofex (CPPU) on yield and bunch quality of Thompson seedless grapevines. Egypt. J. Agric. Res., 79(2): 531549. 
Ministry of Agriculture and Land Reclamation, A.R.E. (2001). Pest Control Programme (in Arabic). pp. 131-136.

M.W.H.C.A. (Ministry of Welfare, Health and Cultural Affairs), Netherlands (1988). Analytical Methods for Residues of Pesticides in Food Stuff.

M.H.W.S. (2006) (Ministry of Health, Welfare and Sport. (2006),. Maximum Residue Limits of Pesticides in Food in the Netherlands. Annex II: 41. The Hague, The Netherlands.

Walgenbach, J.F.; R.B. Leidy and T.J. Sheets (1991). Persistence of insecticides on tomato foliage and implications for control of tomato fruit worm. J. Econ. Entomol. 84: 978-986.

Singh, K.; R.J. Weaver and J.O. Johanson (1978). Effect of applications of gibberellic acid on berry size, shutter and texture of Thompson Seedless grapes. Am. J. Enol. Vitic, 29: 258-262.

Tawfik, Mona H. and A.G. El-Sisi (1987). The effect of mixing some foliar fertilizers on the physical properties and insecticidal activity of some locally spray oils against the scale insect Parlatoria Ziziphus (Lucas). $2^{\text {nd }}$ Naf. Conf. of Pests \& Dis. of Vegt. \& Orchard, Ismaillia, Egypt, pp. 367-376. 